\title{
Early loss of the retinoblastoma gene is associated with impaired growth inhibitory innervation during melanotroph carcinogenesis in $R \boldsymbol{b}^{+/-}$mice
}

\author{
Alexander Yu. Nikitin and Wen-Hwa Lee ${ }^{1}$ \\ Center for Molecular Medicine/Institute of Biotechnology, The University of Texas Health Science Center at San Antonio, \\ San Antonio, Texas, 78245 USA
}

\begin{abstract}
To better understand the cell lineage-specific character of retinoblastoma $(R b)$ gene inactivation during tumor formation, the earliest stages of spontaneous melanotroph carcinogenesis in $R \boldsymbol{b}^{+/-}$heterozygous mice have been subjected to sequential analyses. The first atypical cells are detected in the pituitary intermediate lobe during a period corresponding to the cessation of melanotroph proliferation between 35 and 60 days after birth. Atypical cells contain no wild-type copy of the $R \boldsymbol{b}$ gene and synchronously form early atypical proliferates (EAP) in the subsequent 30-60 day period. In contrast to surrounding mature melanotrophs with the wild-type $R b$ gene, $R b$-negative cells in EAP continue to proliferate well past postnatal day 60 , and fail to be innervated by growth inhibitory dopaminergic nerve terminals. Atypical melanotrophs remain competent for dopamine D2 receptor stimulation and undergo S-phase apoptosis in close proximity to nerve terminals. These results indicate a key role for the $\mathrm{Rb}$ protein in the onset of neuron-neuroendocrine cell interactions. This role may explain cell-type-specific neuroendocrine carcinogenesis associated with inactivation of the ubiquitously expressed $R \boldsymbol{b}$ gene.
\end{abstract}

[Key Words: Apoptosis; dopamine; malignant transformation; pituitary gland; small cell lung carcinoma; tumor suppressor gene]

Received April 9, 1996; revised version accepted June 12, 1996

The retinoblastoma $(R b)$ gene product is involved in cell cycle regulation, differentiation, and cell survival. Inactivation of the gene may contribute to tumor formation (for review, see Riley et al. 1994b; Chen et al. 1995). Although different aspects of $\mathrm{Rb}$ protein functions and the effects of $R b$ alterations have been studied intensively for a substantial period of time, little is known about most proximal consequences of the loss-of-function of $\mathrm{Rb}$ during carcinogenesis in vivo. Moreover, it is unclear how normal physiological functions of the gene product may dictate a specific pattern of subsequent genetic and phenotypical events leading to full malignant transformation. Although the majority of cell types expresses detectable amounts of $\mathrm{Rb}$ protein, only limited numbers, notably those of neural and neuroendocrine origin, consistently lose $\mathrm{Rb}$ function during malignant transformation. In humans, inactivation of $R b$ is most frequently detected in retinoblastoma, small cell lung carcinoma, and lung carcinoids (Bookstein and Lee 1991). Similarly, $\mathrm{Rb}^{-1-}$ melanotroph tumors of the pituitary, C-cell tumors of thyroid gland, and hyperplastic

${ }^{1}$ Corresponding author. neuroendocrine cells in lungs and adrenal medulla are described in both $\mathrm{Rb}^{+1-}$ mice and in chimeric mice with $R b$-deficient cells (Hu et al. 1994; Maandag et al. 1994; Riley et al. 1994a; Williams et al. 1994a,b; Harrison et al. 1995; A.Yu. Nikitin, unpubl.). Consistently, only certain cell lineages, notably neurons, are affected by $\mathrm{Rb}$ loss-of-function during development (Lee et al. 1994). It is therefore possible to envision the existence of common neuroendocrine-specific mechanisms underlying malignant transformation associated with $R b$ loss.

Comprehensive analysis of the role of the $R b$ gene in the process of malignant transformation has became possible with the establishment and characterization of an animal model system in which inactivation of the $R b$ gene appears to be critical for carcinogenesis. Over $95 \%$ of mice with a single copy of functional $R b$ die between 300 and 400 days after birth with melanotroph tumors of the intermediate lobe of the pituitary gland ( $\mathrm{Hu}$ et al. 1994; Maandag et al. 1994; Riley et al. 1994a; Williams et al. 1994b; Harrison et al. 1995). The precise location and small size of the homogeneous target cell population, together with the synchronous and reproducible character of melanotroph tumor development, make this 
model of carcinogenesis particularly attractive for sequential analyses.

Mouse pituitary gland anterior and intermediate lobes arise from Rathke's pouch, an invagination of ectodermal cells which forms adjacent to the anterior neuropore during gestational days (GD) 9 and 10 (Rugh 1990). Though the precise sequence of pituitary precursor cell commitment is unknown (Voss and Rosenfeld 1992), carcinogenic alteration of a potential precursor cell common to melanotrophs and other pituitary cell lineages is unlikely. Cells of melanotroph tumors synthesize only the prohormone pro-opiomelanocortin (POMC) and products of its post-translational processing, including $\alpha$-melanocyte stimulating hormone (MSH) and $\beta$-endorphin (Hu et al. 1994). Moreover, no adrenocorticotrophic tumors are detected in $R b^{+1-}$ mice. Thus, GD 14, the time when the mouse pituitary intermediate lobe can first be identified (Rugh 1990), represents an approximate earliest time for the initiating event in melanotroph carcinogenesis.

Development of retinoblastoma, a pediatric eye tumor, requires the loss of both alleles of the $R b$ gene (Knudson 1971; Cavenee et al. 1983). Identification of the $R b$ gene, characterization of its alterations in patients with retinoblastoma, and subsequent demonstration of tumor suppression by $R b$ gene reintroduction have furnished strong genetic support for this concept (for review, see Riley et al. 1994b). The critical role of complete $R b$ loss for tumor development was also suggested by the rescue of the tumor phenotype in $R b^{+/-}$ mice with germ-line transmission of additional copies of a human $R b$ transgene (Chang et al. 1993). Until now, however, there has been no direct proof that inactivation of the last wild-type $R b$ copy is indeed an early event during carcinogenesis.

In the present paper, we identify, characterize, and trace the earliest stages of the malignant transformation associated with inactivation of the $R b$ gene. Loss of the $R b$ gene results in continuous proliferation and delay of melanotroph maturation, as evidenced by impaired innervation of $R b^{-1-}$ cells. Failure to establish appropriate dopaminergic growth inhibitory nerve contacts may, in turn, promote aberrant cell proliferation and eventual selection of atypical cellular clones. These findings are a first step toward our understanding of gene- and celllineage-specific formation of both animal and clinically relevant human $R b$-deficient neuroendocrine tumors.

\section{Results}

First atypical cells of melanotroph lineage are detected early during the postnatal development of $\mathrm{Rb}^{+/}-$mice

To define the sequence of events preceding the onset of overtly malignant tumors, we have compared different stages of pituitary development from GD 14 onward in wild-type and $R b^{+/-}$mice. In our mouse model, as in the ontogenesis studies of the rat pituitary intermediate lobe (Carbajo et al. 1992; Gary and Chronwall 1992;
Rene et al. 19931, proliferation of melanotrophs decreases after postnatal day (PND) 1, and ceases almost completely between PND 35 and 60 (Fig. 1). No difference is observed between the proliferation rates of $R b^{+1+}$ and $R b^{+1-}$ melanotrophs, indicating no significant effect of $R b$ gene dosage on proliferation. By PND 35 , the intermediate lobe of the mouse pituitary gland is an anatomically well-defined structure (Fig. 2A) with an average size of a few cubic millimeters ${ }^{3}$, is $<300 \mu \mathrm{m}$ thick in dorsoventral aspect, and is composed of about $2 \times 10^{5}$ cells in adult mice ( $\mathrm{Hu}$ et al. 1994; this study). From PND 35 onward, groups of irregularly oriented cells, or early atypical proliferates (EAPs), with clear deviations from the normal cytological appearance of the maturing melanotrophs, are detected in the $R b^{+1-}$ intermediate lobe (Fig. 2B). These earliest atypical cells contain large irregular nuclei with a dense network of chromatin and relatively little pale cytoplasm. In contrast to other cells of the intermediate lobe, atypical cells continue to proliferate intensively beyond PND 60, as demonstrated by both $5^{\prime}$-bromodeoxyuridine (BrdU) labeling (Fig. 2C,D) and frequent mitotic figures. Like cells in gross tumors (Hu et al. 1994), EAP cells express melanotroph-specific $\alpha-\mathrm{MSH}$, albeit less homogeneously compared to surrounding mature melanotrophs (Fig. 2D). It is also important to note that EAPs are frequently detected at the border with the posterior (neural) lobe of the pituitary gland.

By PND 90, nearly all mice have at least one EAP. The average number of EAPs and subsequent invasive tumors per pituitary remains constant until PND 180 (Table 1). At later ages, some tumors replace most of the intermediate lobe; therefore, precise counting and localization of foci is not possible. Given the very low rates of cellular proliferation after PND 35 (Fig. 1), the stochastic initiation event in carcinogenesis is likely to occur within the 6-week period between GD 14 and PND 35, a window in good agreement with the synchronous appearance of the first morphologically identifiable atypical cells (Table 1; Fig. 3). The stable number of EAPs during subsequent

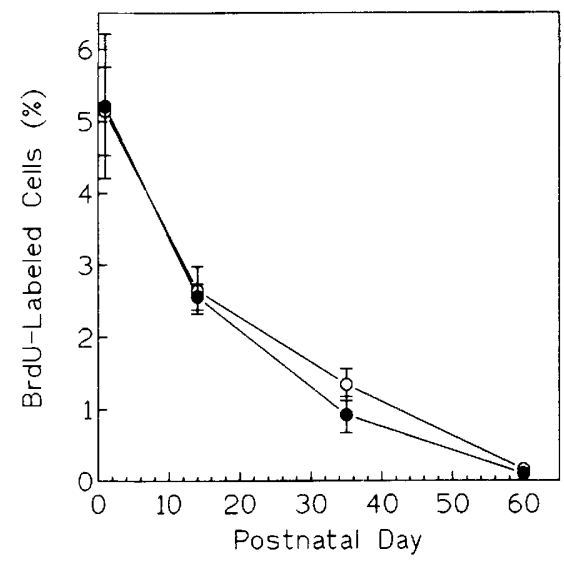

Figure 1. Proliferation of melanotrophs in the pituitary intermediate lobe during development of wild-type $(O)$ and $R b^{+1-}$ (O) mice. All results are presented as means \pm S.E.M. 
Figure 2. Early stages of melanotroph carcinogenesis in $R b^{+1-}$ mice. $(A)$ Horizontal section of the pituitary gland at PND 35. (AL, IL, and PL) Anterior, intermediate, and posterior lobes, respectively. $(B)$ The earliest morphologically detectable group of proliferating atypical cells (arrow) is located at the border with the PL on PND 35. Note high nuclear/cytoplasmic ratio, irregular shape of nuclei, and coarse chromatin. Several cells are in prophase. $\{C\}$ Intensive incorporation of $\mathrm{BrdU}$ by S-phase cells in EAPs (arrow) on PND 60. Hematoxylin counterstain. $(D)$ Expression of $\alpha-\mathrm{MSH}$ in EAP cells (arrow) incorporating BrdU (brown nuclei). BrdU-MSH double immunostaining (nuclear Fast Red counterstain). (E) Wild-type pituitary gland stained for $\mathrm{Rb}$ protein with $\mathrm{C}-15$ peptide antiserum. Note that practically all melanotrophs contain Rb protein at PND 60, whereas endothelial cells and some glial cells (arrowheads) in both IL and PL do not. $\{F \mid \mathrm{Rb}$ staining is absent in the cells of EAP (arrow) on PND 60 (hematoxylin counterstain). $(G, H)$ EAPs stained with hematoxylin and eosin on PND 60, before and after microdissection. Bar, $200 \mu \mathrm{m}|A| ; 10 \mu \mathrm{m}(B) ; 30 \mu \mathrm{m}(C, D) ; 60 \mu \mathrm{m}(E)$; $20 \mu \mathrm{m}(F-H)$.
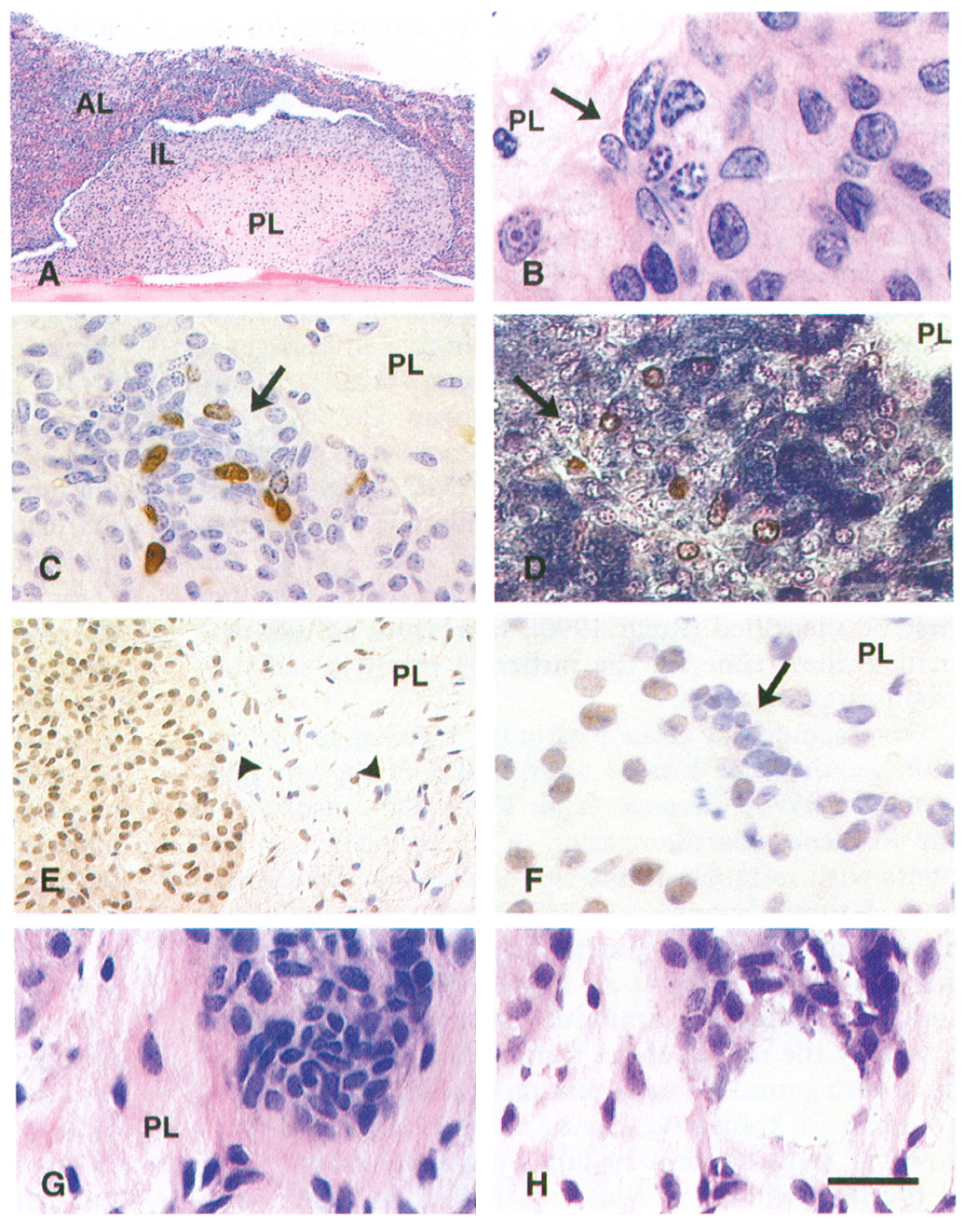

stages of carcinogenesis further supports absence of any significant addition of newly transformed cells after this time window.

Tumors with variable degrees of cellular polymorphism invade posterior and anterior lobes of the pituitary, become hemorrhagic and necrotic, and eventually result in death of mice as a result of invasion and compression of the basal brain structures after PND $300 / \mathrm{Hu}$ et al. 1994; Maandag et al. 1994; Riley et al. 1994a; Williams et al. 1994b; Harrison et al. 1995). Thus, though clinically detectable tumors appear late in the adult life of animals, initiating events of carcinogenesis occur much earlier, during perinatal development.

\section{Early loss of the $\mathrm{Rb}$ gene during melanotroph carcinogenesis}

To test whether inactivation of the last wild-type $R b$ copy is an early event during carcinogenesis, we analyzed $R b$ expression in developing pituitary glands. As opposed to fibroblasts, glia, endothelial cells, and subpopulations of anterior lobe pituicytes, all melanotrophs demonstrate abundant $\mathrm{Rb}$ protein in their nuclei by $\mathrm{PND}$
Table 1. Incidence of melanotroph EAPS in $\mathrm{Rb}^{+1-}$ mice

\begin{tabular}{rlllcc}
\hline $\begin{array}{l}\text { Age } \\
\text { (days) }\end{array}$ & $\begin{array}{l}\text { No. } \\
\text { of } \\
\text { mice }\end{array}$ & $\begin{array}{l}\text { No. of } \\
\text { mice with }\end{array}$ & $\begin{array}{l}\text { No. of foci } \\
\text { EAP })^{\mathbf{2}}\end{array}$ & $\begin{array}{l}\text { Percent of } \\
\text { mouse } \pm \text { S.D. }\end{array}$ & $\begin{array}{l}\text { EAP at } \\
\text { the neural } \\
\text { lobe border }\end{array}$ \\
\hline 14 & 12 & 0 & - & - & - \\
21 & 13 & 0 & - & - & - \\
35 & 11 & 1 & $(9)$ & 1 & 100 \\
60 & 32 & 23 & $(72)$ & $2.2 \pm 1.1$ & 68 \\
90 & 18 & 17 & $(94)$ & $3.6 \pm 1.3$ & 63 \\
120 & 17 & 17 & $(100)$ & $3.3 \pm 1.4$ & 73 \\
140 & 15 & 15 & $(100)$ & $3.7 \pm 1.2$ & 66 \\
180 & 13 & 13 & $(100)$ & $3.5 \pm 1.0$ & 80 \\
\hline
\end{tabular}

Serial sections of paraffin-embedded pituitaries were stained with hematoxylin and eosin and then analyzed with 400- to 600 -fold magnification. The number and location of the foci were recorded after three-dimensional reconstruction of the specimen.

${ }^{a}$ Both EAP and invasive tumors were identified and included for counting after PND 120. 


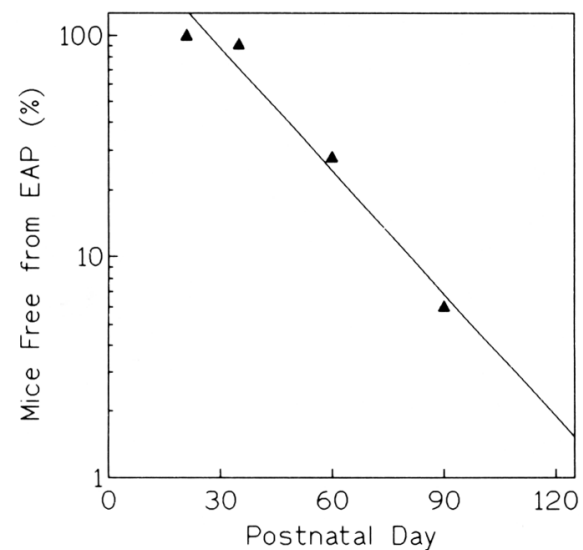

Figure 3. Development of early atypical proliferates in $R b^{+1-}$ mice. The one-hit curve was calculated from $\log \mathrm{Y}=-\mathrm{X} / 54$ $\left(r^{2}=0.9690\right)$. Note that one-hit curve for hereditary cases of retinoblastoma is $\log \mathrm{Y}=-\mathrm{X} / 30\left(r^{2}=0.9851\right)$ (Knudson 1971).

60, after immunostaining with either C-15 antisera or mAb Ab5 (Fig. 2E). In contrast, no staining is detected in the earliest morphologically identifiable atypical cells (Fig. 2F).

To confirm immunohistochemical observations, as well as to identify the genetic mechanism leading to $\mathrm{Rb}$ protein deficiency, cells of EAP were analyzed by a semiquantitative PCR method (see Materials and methods) for loss of the wild-type allele. In preliminary experiments, by mixing known amounts of DNA from $R b^{+1-}$ and $R b^{-1-}$ cells, we were able to estimate that contaminating $R b^{+/-}$cells $\leqslant 30 \%$ of the total could be tolerated for unambiguous detection of the wild-type allele loss (data not shown). Therefore, EAP with minimal stromal components were selected histologically and subjected to careful microdissection (Fig. 2G,H). In agreement with observations on gross melanotroph tumors (Chang et al. 1993; Riley et al. 1994a; Harrison et al. 1995), loss of heterozygosity for the wild-type $R b$ allele was detected in all 22 EAPs analyzed (Fig. 4; data not shown). Thus, inactivation of $\mathrm{Rb}$ functions results from loss of the last copy of the wild-type $R b$ gene and is a very early event during melanotroph carcinogenesis. Similarities between the length of an initiation-prone developmental window and period of time required for the development of $R b$-negative EAPs strongly indicates loss of the $R b$ gene as the initiation event of melanotroph carcinogenesis. Proliferation and maturation of melanotrophs are negatively controlled by hypothalamic dopaminergic innervation projected from the neural lobe during first days of the postnatal development (Schmitt et al. 1981; Davis et al. 1984; Hindelang et al. 1990; Gary and Chronwall 1992; Rene et al. 1993). The possibility that primary $R b$ inactivation occurs in regulatory hypothalamic neurons is, however, unlikely. As a result of innervation plasticity, defects of single neurons should not critically affect regulation of target cells. Moreover, no massive neuronal death has been observed in hypothalamic regions responsible for innervating the pituitary in $R b^{+/-}$mice. In brain samples from eight mice at GD 14.5, the apoptotic rates of hypothalamic neurons were $0.35 \pm 0.14 \%$ and $0.37 \pm 0.13 \%$ (土S.E.M.; $P=0.9135)$ for $R b^{+1+}$ and $R b^{+1-}$ mice, respectively. Finally, the exponential rate of $R b$ negative EAP formation (Fig. 3) is in good agreement with the Knudson's two-hit hypothesis, where a single event is required in a hereditary type of tumor (Knudson 1971). Primary $R b$ inactivation in growth inhibitory neurons with later loss of $\mathrm{Rb}$ function in atypical melanotrophs would represent two subsequent hits after heterozygous germ-line $\mathrm{Rb}$ inactivation, and thus, would contradict the single-hit kinetics demonstrated in this study. Therefore, loss of the $R b$ gene by developing melanotrophs, not by connecting neurons, is the most likely initiation event in melanotroph carcinogenesis.

\section{Defective dopamine growth inhibitory innervation in EAPS}

The long latency period between initial formation of EAPs and appearance of invasive tumors with clinical

A

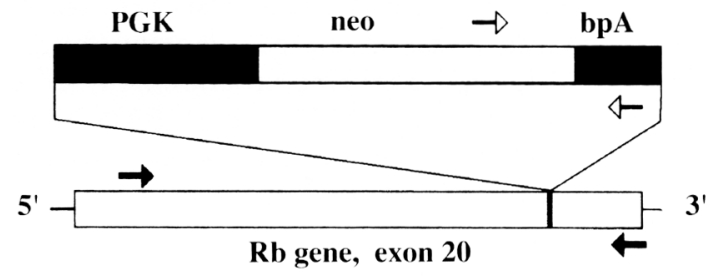

Expected PCR products: Primers for exon 20: $151 \mathrm{bp}$ Primers for neo cassette: $236 \mathrm{bp}$

B

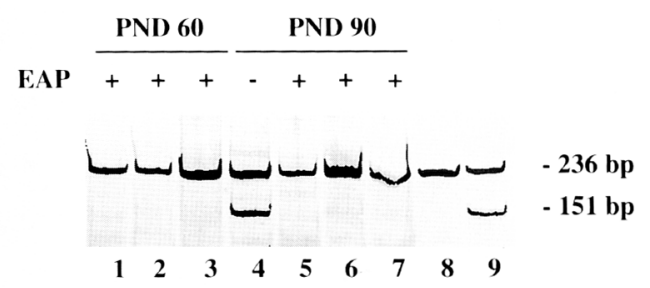

Figure 4. Loss of heterozygosity for the $R b$ gene during melanotroph carcinogenesis. (A) Design of primers for detection of exon 20 of the wild-type $R b$ gene and of the neomycin cassette integrated during the homologous recombination to generate mutant $R b$. (PGK) Phosphoglycerate kinase promoter (neo) gene for neomycin resistance; (bpA) bovine polyadenylation signal. In the case of the neo cassette integration, amplification with exon-specific primers results in a DNA fragment of $\sim 1.7 \mathrm{~kb}$ and is not efficient under the PCR conditions chosen. (B) Loss of the wild-type $R b$ copy in EAPs on PND 60 and 90. The PCR product from the EAP shown in Fig. $2(G, H)$ is in lane 1. (Lanes 2-7) PCR products from other microdissected EAPs $\mid+1$ and surrounding normal melanotrophs $(-)$. (Lanes 8 ,9) Tissue samples from $R b^{-1-}$ and $R b^{+1-}$ mouse embryos on GD 14.5. Nondenaturing $12 \%$ polyacrylamide gel stained with silver. 
manifestations indicates a requirement for additional alterations during tumor progression after $R b$ gene loss. Formation of appropriate growth inhibitory innervation correlates with cessation of melanotroph proliferation and is an integral feature of melanotroph differentiation. Evaluation of melanotroph proliferation and melanotroph interactions with nerve terminals may, therefore, be useful in the search for alterations secondary to the loss of $\mathrm{Rb}$ functions. Moreover, identification of biological implications of the $\mathrm{Rb}$ inactivation is important for understanding the normal biological functions of $\mathrm{Rb}$ protein in neurosecretory cells. To test whether innervation of EAP cells remains intact after $R b$ loss, nerve terminals in the pituitary intermediate lobe were identified by immunostaining for tyrosine hydroxylase, a rate-limiting enzyme of dopamine synthesis, and two other proteins associated with synapses, synaptophysin, a synaptic vesicle membrane protein (Wiedenmann and Franke 1985; Navone et al 1986), and F1-20/AP-3 protein, a synapsespecific clathrin assembly protein (Sousa et al. 1992; Ye and Lafer 1995). Morphologically normal melanotrophs are surrounded by a dense network of nerve terminals, but few nerve terminals can be detected between cells of EAP (Fig. 5A-C). In addition, EAP cells in close proximity to nerve terminals of the surrounding tissue often have fragmented nuclei and condensed chromatin. Terminal deoxytransferase-mediated deoxyuridine nick end-labeling (TUNEL) confirms programmed cell death (apoptosis) in these cells (Fig. 5D). In 12 EAPs analyzed, $94 \pm 3 \%$ ( \pm S.E.M.) of apoptotic cells were located near nerve terminals. To evaluate the connection between proliferation and apoptosis of cells of EAPs, cells synthesizing DNA were analyzed at different time points after BrdU injection. BrdU is detected in pyknotic nuclei of cells undergoing apoptosis (Fig. 5E) and in mitotic cells (not shown), respectively, 2 and $4 \mathrm{hr}$ after administration. In 10 EAPs analyzed $34 \pm 4 \%$ ( \pm S.E.M.) of apoptotic cells were labeled $6 \mathrm{hr}$ after BrdU administration. Thus, significant portions of atypical cells undergo apoptosis after entering $S$ phase of the cell cycle.

As demonstrated by immunostaining, atypical melanotrophs express dopamine D2 receptors (not shown). To test whether EAP cells remain competent for the dopamine D2 receptor stimulation, a dopamine agonist (bromocriptine) was administered intraperitoneally to animals on PND 90. As it did for normal melanotrophs (Rychter and Stepien 1977; Chronwall et al. 1987), bromocriptine significantly reduced BrdU incorporation in cells of EAP (Fig. 6A). At the same time, the apoptotic index increased twofold. This effect is consistent with the observation of apoptosis of atypical cells in close proximity to nerve terminals. After application of extra physiological levels of the dopamine agonist, significant portions of atypical apoptotic cells were remote from nerve terminals $[29 \pm 4 \%$ vs. $6 \pm 3 \%$ in control ( \pm S.E.M.), $P=0.0002$ ]. In agreement with previous reports (Rychter and Stepien 1977; Chronwall et al. 1987), apoptotic cells could not be detected among normal melanotrophs after exposure to bromocriptine. Moreover, there was no detectable increase in the apoptotic rate of proliferating melanotrophs during the physiological onset of dopaminergic innervation $[0.044 \pm 0.037 \%$ and $0.014 \pm 0.014 \%$,
Figure 5. Aberrant innervation of atypical cells. Immunostaining for tyrosine hydroxylase $(A), \mathrm{F} 1$ $20(B)$, and synaptophysin $(C)$ with hematoxylin counterstain. Note practical absence of innervation between EAP cells $(A$, bottom; $B$, right; $C$, leftl, and apoptotic figures in close proximity to nerve terminals (arrows). (D) Programmed cell death of atypical cells (arrow). TUNEL technique, counterstained with methyl green. $(E)$ Apoptosis of atypical cells after S-phase entrance, $2 \mathrm{hr}$ after BrdU labeling. Note condensed chromatin of BrdU-positive nuclei of apoptotic cells (arrows) (methyl green counterstain). (B,D) PND 60; $(A, C, E)$ PND 90. $\operatorname{Bar}, 30 \mu \mathrm{m}(A) ; 15 \mu \mathrm{m}(B, E) ; 20 \mu \mathrm{m}(C, D)$.
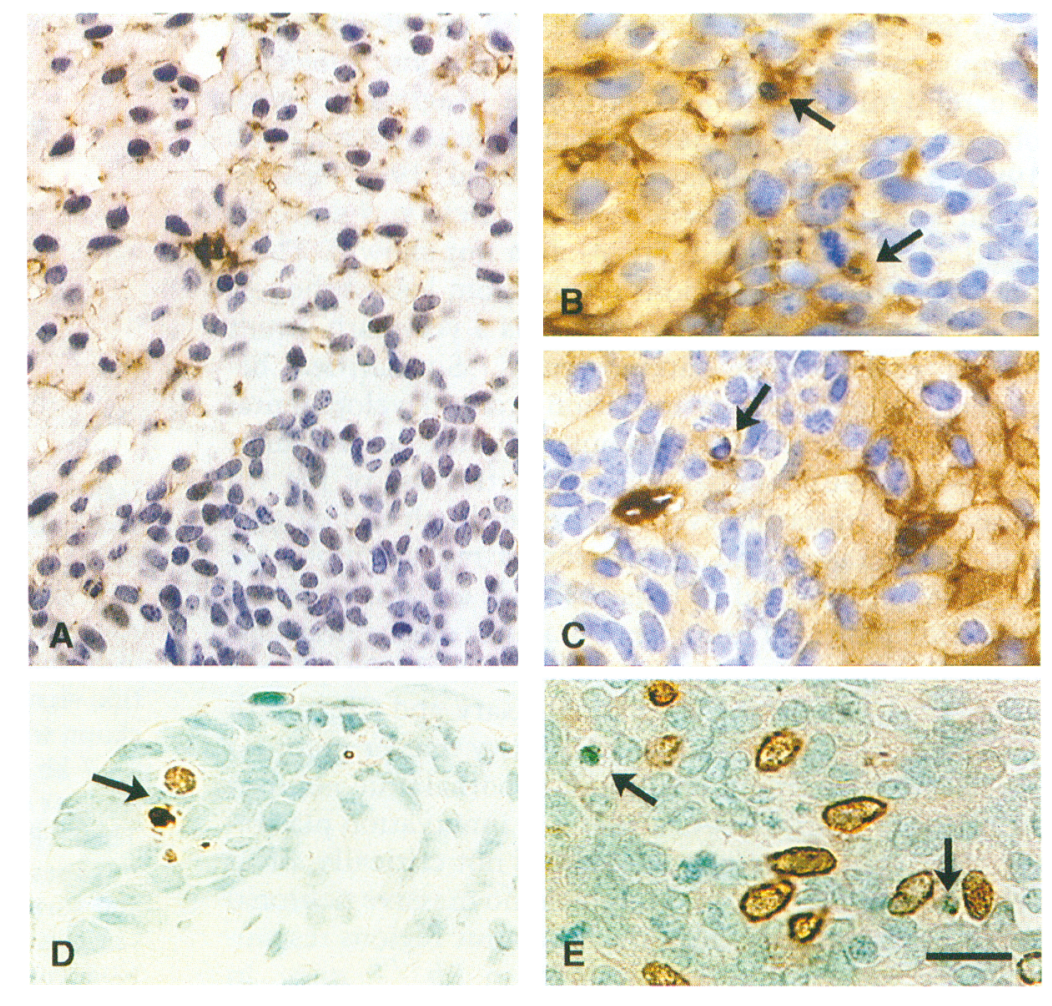
A

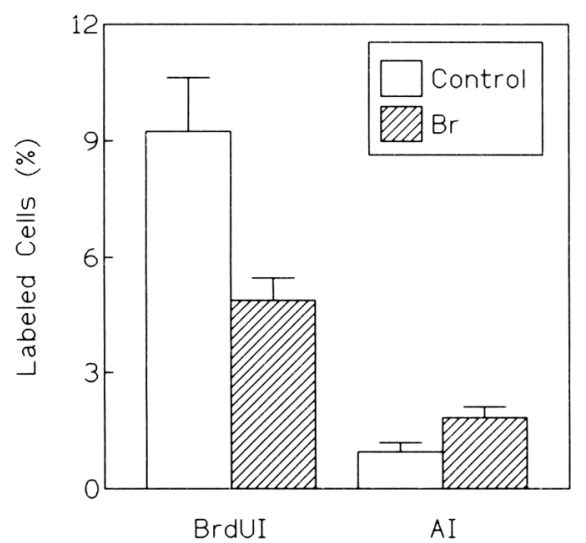

B

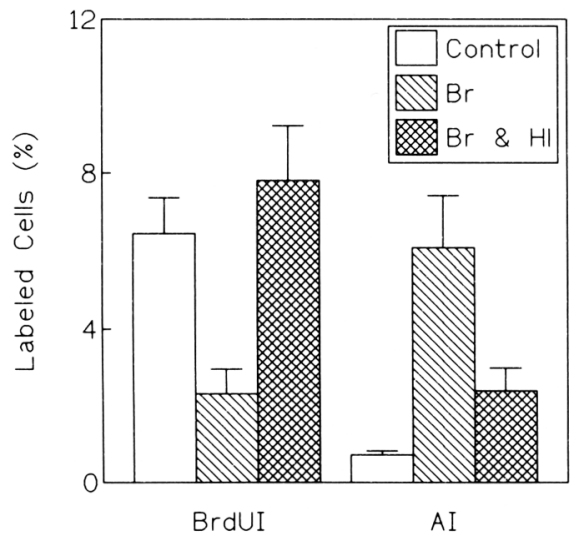

Figure 6. Effects of bromocriptine and haloperidol on $R b$-deficient melanotrophs. $(A)$ Effect of bromocriptine $(\mathrm{Br})$ administration in vivo (see Materials and methods for details) on BrdU and apoptotic indices (BrdUI and AI) of EAP cells on PND 90. Twotailed $P$ values for BrdUI and AI are 0.0311 and 0.0438 , respectively. $(B)$ Inhibition of the effects of $\mathrm{Br}\left(10^{-7} \mathrm{M}\right)$ by haloperidol $\left(\mathrm{Hl}, 10^{-5} \mathrm{M}\right)$ on BrdUI and AI of melanotroph tumor MT-4 cells. All experiments were performed twice in triplicate. Two-tailed $P$ values (control vs. Br) are 0.0103 (BrdUI) and 0.0071 (AI). All results are presented as mean \pm S.E.M.

before innervation, GD 1, and after innervation, GD 14, respectively ( \pm S.E.M.), $P=0.4969$ ]. To exclude indirect effects of bromocriptine on the EAP cells, cells from a newly established melanotroph tumor cell line MT-4 were treated with bromocriptine in culture. As with the in vivo results, application of bromocriptine decreased proliferation of melanotrophs, and enhanced their apoptotic rate. Both effects were completely prevented by excess amounts of the dopamine antagonist haloperidol (Fig. 6B). Taken together, these data exclude downstream placement of the $\mathrm{Rb}$ protein in dopaminergic growth inhibition, demonstrate deficiency in the differentiation of Rb-negative melanotrophs, and indicate a primary role of $R b$ inactivation in failure to establish appropriate neuron-target cell interactions.

\section{Discussion}

The timing of the appearance of $R b$-negative EAPs argues for an important role for the $R b$ gene in appropriate withdrawal of melanotrophs from proliferation. Similar functions of the $R b$ protein have been suggested for developing neurons after analyses of $R b^{-1-}$ mice (Lee et al. 1994). The continuous presence of the $\mathrm{Rb}$ protein in mature melanotrophs indicates further requirements for $\mathrm{Rb}$ in the maintenance of a differentiated state. This conclusion is in agreement with findings of permanent $R b$ expression in many terminally differentiated cells of mice and humans: Significant accumulation of the $\mathrm{Rb}$ protein is observed in neurons and neuroendocrine cells of the adrenal, thyroid, and pancreatic glands (Szekely et al. 1992; Cordon-Cardo and Richon 1994; A.Yu. Nikitin and W.-H. Lee, unpubl.).

In addition to continuous proliferation, the main difference between the earliest morphologically distinct $R b$-negative cells and mature melanotrophs is the lack of innervation in the former. The majority of EAPs form on the border with the pituitary neural lobe, the earliest site of melanotroph innervation and maturation. Because no preferential proliferative activity of melanotrophs at the neural lobe border has been observed, and as the time interval for the $R b$ loss is limited, we suggest that selection of the $R b$-negative cells may require a specific critical environment provided by surrounding maturing melanotrophs and/or nerve terminals. Regulation of melanotroph precursor cells greatly depends on direct dopaminergic innervation by axons of mediobasal hypothalamic neurons. A series of studies based on pituitary stalk transections, pharmacological modifications of dopamine receptor activation, and ontogenetic correlations has demonstrated tonic inhibitory effects of dopaminergic innervation on melanotroph proliferation. Dopaminergic innervation also inhibits the synthesis and secretion, respectively, of POMC and its melanotrophspecific cleavage products (Schmitt et al. 1981; Rene et al. 1993). During the first days of postnatal development, dopaminergic innervation appears at the border between the neural and intermediate lobes, expands in a gradientlike fashion, and soon becomes evenly distributed around cells (Schmitt et al. 1981; Davis et al. 1984; Gary and Chronwall 1992; Rene et al. 1993). This neural network ensures a mature state of hormonal synthesis, processing, and secretion by PND 60 (Tong and Pelletier 1990). The observation of increased concentrations of $\alpha-\mathrm{MSH}$ in the blood of $\mathrm{Rb}^{+/-}$mice during the first 6 months of postnatal development (Hu et al. 1994) also fits well with the concept of loss of inhibitory dopaminergic regulation of secretion by melanotrophs undergoing malignant transformation.

How $\mathrm{Rb}$ expression influences innervation of melanotrophs remains to be resolved. Apparently, the failure in the development of dopaminergic innervation in $\mathrm{Rb}^{-1-}$ melanotrophs is not caused by the deficiency of the dopamine D2 receptor. Our experiments, both in vivo and in cell culture, demonstrated preservation of the D2 receptor-mediated response in $R b$-negative melano- 
trophs. The expression of the D2 receptorinmouse melanotrophs is detected as early as the last days of gestation (Rene et al. 1993). The Rb protein is not known to have a direct role in the regulation of $\mathrm{D} 2$ receptor expression. However, Rb does play a critical role in the cell cycle and differentiation process (for review, see Riley et al. 1994; Chen et al. 1995). These functions are consistent with the requirement of initial inactivation of the $R b$ gene for the malignant transformation of melanotrophs. Moreover, a similar role for the $\mathrm{Rb}$ protein may be critical in the preparation of the melanotrophs for appropriate responses to, and interactions with, neurons. In this scenario, $\mathrm{Rb}$ activation would support timely exit of cells from the cell cycle and maintain them in the $G_{0}$ state before a connection to regulatory nerve terminals can be established.

At present, little is known about neurotrophic factors involved in the normal development and innervation of melanotrophs. Though a neurotrophic activity of $\alpha-\mathrm{MSH}$ has been demonstrated (Demeneix and Grant 1988; Gispen 1993; Strand et al. 1993), expression of $\alpha$-MSH by atypical melanotrophs is apparently insufficient for establishment of appropriate innervation. By analogy, melanotroph lineage-specific biological roles of factors known to be expressed in the pituitary intermediate lobe, such as brain-derived neurotrophic factor (Kononen et al. 1994) and nerve growth factor (Soinila et al. 1988), remain to be clarified. The impaired innervation of melanotrophs reflects their immature state; more complete information about the role of $\mathrm{Rb}$ in development and the malignant transformation of melanotroph lineage will be possible after identification and characterization of other traits associated with melanotroph differentiation, such as those involving adhesion molecules, receptor expression, extracellular matrix formation, and so forth.

The impaired ability of $R b^{-1-}$ cells to establish connections required for regulation by neurons may provide a more general clue to the neuron and neuroendocrine cell lineage-specificity of the alterations associated with $R b$ inactivation. Failure of the $\mathrm{Rb}$-mediated onset of neuron-neuron innervation may, at least in part, explain the excessive programmed neuronal cell death observed in $R b^{-1-}$ mouse embryos at the time of extensive synaptogenesis (Lee et al. 1994). By analogy with neuronneuron interactions, precise neuron-neuroendocrine innervation is required during formative stages of development. For example, specific innervation of neuroendocrine cells in lungs has been described (Pack and Widdicombe 1984). Interestingly, expression of D2 receptors and growth inhibitory effects of bromocriptine similar to those observed in our experiments with the MT-4 cell line have been reported in experiments on cell lines derived from small cell lung carcinoma (Ishibashi et al. 1994). Like melanotroph tumors, small cell lung carcinomas derive from neuroendocrine cells of ectodermal origin and almost always harbor $R b$ mutations. Defective innervation has also been reported in tumors of human adrenal medulla (DeLellis et al. 1983) and equine pituitary intermediate lobe (Millington et al.
1988). The $R b$ status of these tumors remains to be clarified.

Although no distinct increase in apoptotic rate is observed before EAP appearance, proliferating $R b$-negative atypical cells in the immediate vicinity of dopaminergic nerve terminals do undergo apoptosis. The observation of apoptosis after exposure to excess amounts of a dopamine agonist in vivo and in cell culture supports identification of dopamine as a triggering event in the programmed death of melanotrophs. Analogous effects of dopamine were reported in studies on rat phaeochromocytoma PC12 cells (Walkinshaw and Waters 1995), chicken sympathetic neurons (Ziv et al. 1994), and rat somatotropin- and mouse adrenocorticotrophic hormone-producing adenomas (Yin et al. 1993, Yin et al. 1994). Inhibitory effects of MSH-like peptides on the binding of dopamine agonists to dopamine D2 receptor have been described (Florijn et al. 1992). These observations may explain why only cells in the immediate vicinity of the nerve terminals respond to physiological concentrations of dopamine. Programmed cell death occurs after $S$-phase entry of proliferating $R b$-negative atypical cells. This combination indicates the conflicting nature of unscheduled cell proliferation in response to external signals from dopamine, which normally regulates specific differentiated cells at this time of ontogenesis. Similar cell-cycle-dependent apoptosis was reported in ectopically dividing $R b$-deficient neural cells at the time of expected differentiation during embryonic development (Lee et al. 1994), as well as in cases of target-related neuronal death (Herrup and Busser 1995). The cell-lineage specificity of the preferential bias towards either aberrant proliferation or programmed cell death is a likely explanation for the restricted set of $\mathrm{Rb}$-negative tumors.

Taken together, our results argue for inactivation of the $R b$ gene as the initiating event of melanotroph malignant transformation. Failure to establish appropriate innervation may be a second critical step in melanotroph carcinogenesis by promoting aberrant cell proliferation and eventual selection of atypical cellular clones. This finding is encouraging for the development of $R b$ gene transfer techniques to treat cancer. Theoretically, even temporary reconstitution of $\mathrm{Rb}$ function would be sufficient to render atypical cells competent for innervation during early stages of carcinogenesis. Permanent growth inhibition or dopamine-mediated apoptotic death of cells attached to nerve terminals may result in elimination of the target cell pool susceptible to malignant transformation. Experiments testing this hypothesis are currently under way.

\section{Materials and methods}

Animals

Origin and maintenance of $R b$ heterozygous mice were described previously (Lee et al. 1992; Riley et al. 1994a). GD 1 and PND 1 were considered completed, respectively, at midnight of the day after mating, and $24 \mathrm{hr}$ after birth. Wild-type and $R b$ heterozygous mice were genotyped by PCR (see below). 


\section{Cell culture}

A melanotroph tumor $(0.5 \times 0.4 \times 0.3 \mathrm{~cm})$ without visible necroses and hemorrhages was aseptically removed from a 320 -dayold female mouse. Cells were mechanically dissociated by pipetting and placed in Dulbecco's modified Eagle medium (DMEM) supplemented with $10 \%$ fetal bovine serum. Fibroblasts were eliminated by multiple transfers of non-adherent cells onto new dishes every second day. The purity of melanotroph tumor cells was confirmed by PCR genotyping (see below) for loss of the wild-type $R b$ allele. Melanotroph tumor cell line MT-4 was established after 20 passages.

\section{Drug treatment}

For in vivo experiments bromocriptine (2-bromo- $\alpha$-ergocryptine methanesulfonate; $3 \mu \mathrm{g} / \mathrm{gram}$ of body weight, Sigmal was administered i.p. daily for 8 days. Three hours after the last dose, animals were injected with $\mathrm{BrdU}(100 \mu \mathrm{g} / \mathrm{gram}$ of body weight $)$ and sacrificed $\mathrm{l} \mathrm{hr}$ later. Control animals were injected with $10 \%$ ethanol in saline. In cell culture, bromocriptine and haloperidol (Sigma) were applied at $10^{-7}$ and $10^{-5} \mathrm{M}$, respectively, for 2 days (Rene et al. 1993). Cells were labeled with BrdU (100 $\mu \mathrm{M}$ ) for $2 \mathrm{hr}$, cytospun, and fixed in $4 \%$ paraformaldehyde. BrdU labeling and apoptotic indices were determined as described for tissues sections (see below).

\section{Preparation and histological analyses of tissues}

Pituitary glands from $\mathrm{Rb}^{+1+}$ and $\mathrm{Rb}^{+1-}$ animals at GD 14.5, 16.5, and 18.5, and at PND 1, 14, 21, 35, 60, 90, 130, 180, and 240 were either immersed in Bouin's fluid or fixed in phosphatebuffered $4 \%$ paraformaldehyde by cardiac perfusion at $90 \mathrm{~mm}$ $\mathrm{Hg}$ of mice anesthesized with avertin. Pituitary glands were dissected out under a stereo operation microscope (Nikon), labeled with blue Tissue Marking Dye (TBS), and embedded in paraffin (Paraplast X-TRA; Fisher). Four-micron sections were placed onto Superfrost Plus slides (Fisher), stained with Mayer's haemalum and eosin, and mounted in Canada balsam (Fisher). Distribution and size of tumor foci were evaluated at $600-$ and 1000 -fold magnifications. Three-dimensional maps were prepared from at least 12 cases per group per point.

\section{Immunostaining}

Immunohistochemical detection of Rb protein, synaptophysin, F1-20 protein, and tyrosine hydroxylase was performed on paraffin sections of paraformaldehyde-fixed material, with use of the avidin/biotin/peroxidase complex $(\mathrm{ABC})$ method (Nikitin et al. 1991). The following modifications were made. To block free aldehyde groups, sections were placed in PBS containing $0.05 \%$ sodium borohydrate for $10 \mathrm{~min}$. After permeabilization with $0.5 \%$ Triton $\mathrm{X}-100$ for $3 \mathrm{~min}$, nonspecific antibody binding was prevented by blocking B solution $(25 \mathrm{~mm}$ Tris- $\mathrm{HCl}$ at $\mathrm{pH}$ $8.0,100 \mathrm{~mm} \mathrm{NaCl}, 0.2 \% \mathrm{NP}-40,5 \%$ nonfat dry milk, $0.1 \%$ $\mathrm{NaN}_{3}$ ). Affinity-purified rabbit polyclonal antibody raised against a 15-amino-acid peptide within the carboxy-terminal domain of the human $\mathrm{Rb}$ protein $/ \mathrm{C}-15$, Santa Cruz Biotechnology, dilution 1:300), and mouse monoclonal antibodies raised against a 56- $\mathrm{kD}$ carboxy-terminal fragment $(\mathrm{mAb} \mathrm{Ab} 5$, clone LM95.1, Oncogene Science; dilution 1:30) were preabsorbed overnight with tissues of $R b^{-1-}$ mouse embryos to eliminate antibody cross-reactivity with proteins other than $\mathrm{Rb}$. Anti-Rb protein antibodies, as well as the antibodies recognizing synaptophysin (mAb clone SY38, DAKO, dilution 1:200), F1-20/AP-3 protein (Sousa et al. 1990; dilution 1:200), the dopamine syn- thesis rate-limiting enzyme tyrosine hydroxylase /clone TH-2, Sigma, dilution 1:50), and dopamine D2 receptor (Research \& Diagnostic Antibodies, dilution 1:500) were applied to tissue sections for $16 \mathrm{hr}$ at $4^{\circ} \mathrm{C}$. Detection of $\alpha-\mathrm{MSH}$ was as described (Hu et al. 1994).

The specificity of primary antibodies was controlled by absorption with the appropriate respective immunogens, by substitution with respective normal immunoglobulin fraction, and, for anti- $\mathrm{Rb}$ protein antibodies, by staining of sections from viable $R b^{-1-}$ embryos on GD 13.5.

\section{Analyses of proliferative and apoptotic activities}

For determination of BrdU incorporation, material was collected at required time intervals after a single i.p. injection of $\mathrm{BrdU}(100 \mu \mathrm{g} / \mathrm{gram}$ of body weight; Sigma). Immunohistochemical localization of BrdU (Lee et al. 1994), and TUNEL analyses (Gavrieli et al. 1992) were performed as described. BrdU labeling and apoptotic indices were determined microscopically by counts of $\geqslant 500$ cells in dorsal, middle, and ventral sections of individual pituitary glands from three to four animals.

\section{Isolation of DNA}

DNA from white blood cells, fresh tissue fragments, and microdissected paraformaldehyde-fixed material was isolated essentially as described (Nikitin et al. 1993). Microdissection-PCR analyses were performed on routine paraformaldehyde-fixed sections with modifications of the original protocol (Nikitin et al. 1993). The bottom sides of slides were marked with a permanent xylene- and ethanol-resistant marker (Shur/Mark; TBS) beneath histologically selected areas. Images were captured and recorded with C5810 Color Camera (Hamamatsu) and Adobe Photoshop Software. After unmounting with xylene, slides with sections were transferred to ethanol and air-dried. Areas indicated by the marker were placed under a Nikon inverted microscope equipped with phase-contrast and differential interference contrast optics, and their structures were compared with previously digitized images. Tissues were dissected with and collected into glass capillaries $(50-\mu \mathrm{m}$ diam.) mounted on micromanipulator (Leitz), under 600-fold magnification. Capillary tips with dissected material were broken in Eppendorf tubes containing lysis buffer $(50 \mathrm{mM} \mathrm{KCl}, 10 \mathrm{~mm}$ Tris- $\mathrm{HCl}$ at $\mathrm{pH} 8.3$, $2.5 \mathrm{mM} \mathrm{MgCl}_{2}, 0.1 \mathrm{mg} / \mathrm{ml}$ of gelatin, $0.45 \% \mathrm{NP}-40,0.45 \%$ Tween $20,60 \mu \mathrm{g} / \mathrm{ml}$ of proteinase K). After incubation for $1 \mathrm{hr}$ at $56^{\circ} \mathrm{C}$ and denaturation of proteinase $\mathrm{K}$ for $10 \mathrm{~min}$ at $95^{\circ} \mathrm{C}$, samples were ready for further analysis.

\section{PCR analyses}

For genotyping of animal and histological samples, a semiquantitative PCR assay that discriminates between wild-type and mutant $R b$ was established (Fig. 4A). Primers $\mathrm{m} R b$, ex20, 5', 2 (5'-AGTGTACCGTCTAGCATATCTCCGA- $\left.3^{\prime}\right)$ and $\mathrm{m} R b$, ex20, 3' $\left(5^{\prime}\right.$-TACCTGGTCCAAATGTCGGTCTCTC-3') match mouse $R b$ gene sequences upstream and downstream, respectively, of integration of the neomycin cassette in exon 20. Primers neo 5'3 (5'-TGATATTGCTGAAGAGCTTGGCGGC-3') and bpA, 3' (5'-TGGGAGTGGCACCTTCCAGGGTCAA-3') are complementary to the neomycin gene and polyadenylation sequence of the bovine growth hormone gene, respectively.

The reaction mixture for PCR included $50 \mathrm{~mm} \mathrm{KCl}, 10 \mathrm{~mm}$ Tris- $\mathrm{HCl}$ (at $\mathrm{pH} 8.3$ ), $1.5 \mathrm{~mm} \mathrm{MgCl}_{2}, 0.001 \%$ gelatin, dNTPs (200 $\mu \mathrm{M}$ of each), primers (0.4 $\mu \mathrm{M}$ of each), and 0.5 unit of recombinant Taq polymerase (AmpliTaq; Perkin-Elmer), in a final volume of $25 \mu \mathrm{l}$. Amplifications were performed in 50 cycles 
for the DNA from microdissected material and in 30 cycles in all other cases /temperature profile, $94^{\circ} \mathrm{C}$ for $30 \mathrm{sec}^{\circ} 55^{\circ} \mathrm{C}$ for 1 $\min ; 72^{\circ} \mathrm{C}$ for $2 \mathrm{~min}$ ), with elongation of the terminal extension step to $10 \mathrm{~min}$ at $72^{\circ} \mathrm{C}$. Considering the high sensitivity of PCR, reactions were set up in a laminar flow cabinet equipped with UV illumination (Nuaire). All amplifications were carried out in a separate room with separate instrumentation, and always included blank samples without target DNA. The resulting DNA fragments were electrophoresed for $30 \mathrm{~min}$ at room temperature on $4 \%$ NuSieve/SeaKem (3:1, FMC) composite gel. Microdissection-PCR samples were resolved on nondenaturing $12 \%$ polyacrylamide gels, and silver stained as described (Nikitin et al. 1993).

\section{Statistical analyses}

All statistical analyses were performed with the programs InStat and InPlot (GraphPad Inc.).

\section{Acknowledgments}

We thank Dr. Daniel J. Riley and Dr. Z. Dave Sharp for critical reading of the manuscript, Dr. Eileen $M$. Lafer for the kind gift of Fl-20 antibody and advice, Dr. Sergei Yu. Revskoy for insightful discussions, and Dr. Nanpin Hu for useful technical comments during early stages of the project. This work was supported by grants from the National Cancer Institute (CA 58318) and the National Eye Institute (EY 05758).

The publication costs of this article were defrayed in part by payment of page charges. This article must therefore be hereby marked "advertisement" in accordance with 18 USC section 1734 solely to indicate this fact.

\section{References}

Bookstein, R. and W.-H. Lee. 1991. Molecular genetics of the retinoblastoma suppressor gene. CRC Crit. Rev. Oncogenesis 2: 211-227.

Carbajo, S., J.L. Hernandez, and E. Carbajo-Perez. 1992. Proliferative activity of cells of the intermediate lobe of the rat pituitary during the postnatal period. Tissue \& Cell 24: 829834.

Cavenee, W.K., T.P. Dryja, R.A. Phillips, W.F. Benedict, R. Godbout, B.L. Gallie, A.L. Murphee, L.C. Strong, and R.L. White. 1983. Expression of recessive alleles by chromosomal mechanisms in retinoblastoma. Nature 305: 779-784.

Chang, C.-Y., D.J. Riley, E.Y.-H.P. Lee, and W.-H. Lee. 1993. Quantitative effects of the retinoblastoma gene on mouse development and tissue-specific tumorigenesis. Cell Growth Differ. 4: 1057-1064.

Chen, P.-L., D.J. Riley, and W.-H. Lee. 1995. The retinoblastoma protein as a fundamental mediator of growth and differentiation signals. Crit. Rev. Eukar. Gene Express. 5: 79-95.

Chronwall, B.M., W.R. Millington, W.S.T. Griffin, J.R. Unnerstall, and T.L. O'Donohue. 1987. Histological evaluation of the dopaminergic regulation of proopiomelanocortin gene expression in the intermediate lobe of the rat pituitary, involving in situ hybridization and $\left[{ }^{3} \mathrm{H}\right]$ thymidine uptake measurement. Endocrinology 120: 1201-1211.

Cordon-Cardo, C. and V.M. Richon. 1994. Expression of the retinoblastoma protein is regulated in normal human tissues. Am. J. Pathol. 144: 500-510.

Davis, M.D., W. Lichtensteiger, M. Schlumpf, and A. Bruinink. 1984. Early postnatal development of pituitary intermediate lobe control in the rat by dopamine neurons. Neuroendocrinology 39: 1-12.
DeLellis, R.A., A.S. Tischler, A.K. Lee, M. Blount, and H.J. Wolfe. 1983. Leu-enkephalin-like immunoreactivity in proliferative lesions of the human adrenal medulla and extraadrenal paraganglia. Am. I. Surg. Pathol. 7: 29-37.

Demeneix, B. and N.J. Grant. 1988. Alpha-melanocyte stimulating hormone promotes neurite outgrowth in chromaffin cells. FEBS Lett. 226: 337-342.

Florijn, W.J., T. De Boer, J.A.D.M. Tonnaer, and D.H.G. Versteeg. 1992. Characterization of the inhibitory effect of adrenocorticotropin/melanocyte-stimulating hormone-like peptides on the binding of dopamine receptor ligands to the dopamine D2 receptor in vitro. I. Pharmacol. Exper. Ther. 263: 787-792.

Gary, K.A. and B.M. Chronwall. 1992. The onset of dopaminergic innervation during ontogeny decreases melanotrope proliferation in the intermediate lobe of the rat pituitary. Int. I. Dev. Neurosci. 10: 131-142.

Gavrieli, Y., Y. Sherman, and S.A. Ben-Sasson. 1992. Identification of programmed cell death in situ via specific labeling of nuclear DNA fragmentation. I. Cell Biol. 119: 493-501.

Gispen, W.H. 1993. The potential of melanotropins in the treatment of nervous system diseases. Ann. N.Y. Acad. Sci. 680: $401-411$.

Harrison, D.J., M.L. Hooper, J.F. Armstrong, and A.R. Clarke. 1995. Effects of heterozygosity for the $R b-1^{\text {t19neo }}$ allele in the mouse. Oncogene 10: 1615-1620.

Herrup, K. and J.C. Busser. 1995. The induction of multiple cell cycle events precedes target-related neuronal death. Development 121: 2385-2395.

Hindelang, C., J.M. Felix, F.M. Laurent, M.J. Klein, and M.E. Stoeckel. 1990. Ontogenesis of proopiomelanocortin gene expression and regulation in the rat pituitary intermediate lobe. Mol. Cell. Endocrinol. 70: 225-235.

Hu, N., A. Gutsmann, D.C. Herbert, A. Bradley, W.H. Lee, and E.Y.-H.P. Lee. 1994. Heterozygous $R b-1^{\Delta 20 /+}$ mice are predisposed to tumors of the pituitary gland with a nearly complete penetrance. Oncogene 9: 1021-1027.

Ishibashi, M., M. Fujisawa, H. Furue, Y. Maeda, M. Fukayama, and T. Yamaji. 1994. Inhibition of growth of human small cell lung cancer by bromocriptine. Cancer Res. 54: 34423446.

Knudson A.G. 1971. Mutation and cancer: Statistical study of retinoblastoma. Proc. Natl. Acad. Sci. 68: 820-823.

Kononen, J., S. Soinila, H. Persson, J. Honkaniemi, T. Hokfelt, and M. Pelto-Huikko. 1994. Neurotrophins and their receptors in the rat pituitary gland: Regulation of BDNF and trkB mRNA levels by adrenal hormones. Brain Res. Mol. Brain Res. 27: 347-354.

Lee, E.Y.-H.P., C.-Y. Chang, N. Hu, Y.-C.J. Wang, C.-C. Lai, K. Herrup, W.-H. Lee, and A. Bradley. 1992. Mice deficient for $R b$ are nonviable and show defects in neurogenesis and haematopoiesis. Nature 359: 288-294.

Lee, E.Y.-H.P., N. Hu, S.-S.F. Yuan, L.A. Cox, A., Bradley, W.-H. Lee, and K. Herrup. 1994. Dual roles of the retinoblastoma protein in cell cycle regulation and neuron differentiation. Genes \& Dev. 8: 2008-2021.

Maandag, E.C.R., M. van der Valk, M. Vlaar, C. Feltkamp, J. $\mathrm{O}^{\prime}$ Brien, M. van Roon, N. van der Lugt, A. Berns, and H. te Riele. 1994. Developmental rescue of an embryonic-lethal mutation in the retinoblastoma gene in chimeric mice. EMBO I. 13: 4260-4268.

Millington, W.R., N.O. Dybdal, R. Dawson, C. Manzini, and G.P. Mueller. 1988. Equine Cushing's disease: Differential regulation of beta-endorphin processing in tumors of the intermediate pituitary. Endocrinology 123: 1598-1604.

Navone, F., R. Jahn, G. Di Gioia, H. Stukenbrok, P. Greengard, 
and P. De Camilli. 1986. Protein p38: An integral membrane protein specific for small vesicles of neurons and neuroendocrine cells. I. Cell Biol. 103: 2511-2527.

Nikitin, A.Yu., K. Lennartz, K.M. Pozharisski, and M.F. Rajewsky. 1991. Rat model of the human "Triton" tumor: Direct genetic evidence for the myogenic differentiation capacity of schwannoma cells using the mutant neu gene as a cell lineage marker. Differentiation 48: 33-42.

Nikitin, A.Yu., M.F. Rajewsky, and K.M. Pozharisski. 1993. Development of malignant fibrous histiocytoma induced by 7,12-dimethylbenz[a]anthracene in the rat: Characterization of early atypical cells. Virchows Arch. B Cell Pathol. Incl. Mol. Pathol. 64: 151-159.

Pack, R.J. and J.G. Widdicombe. 1984. Amine containing cells of the lung. Eur. J. Respir. Dis. 65: 559-578.

Rene, F., C. Hindelang, P. Vuillez, M. Plante, M.J. Klein, J.M. Felix, and M.E. Stoeckel. 1993. Morphofunctional aspects of melanotrophic cells developing in situ and in vitro. Ann. N.Y. Acad. Sci. 680: 89-110.

Riley, D.J., C.C. Lai, C.-Y. Chang, D. Jones, E.Y.-H.P. Lee, and W.-H. Lee. 1994a. Susceptibility to tumors induced in mice by ethylnitrosourea is independent of retinoblastoma gene dosage. Cancer Res. 54: 6097-6101.

Riley, D.J., E.Y.-H.P. Lee, and W.-H. Lee. 1994b. The retinoblastoma protein: More than a tumor suppressor. Annu. Rev. Cell Biol. 10: 1-29.

Rugh R. 1990. The mouse. Its reproduction and development. Oxford University Press, Oxford, UK.

Rychter, J. and H. Stepien. 1977. Effects of pimozide and bromocriptine on the proliferation of rat pituitary pars intermedia cells. J. Endocrinol. 75: 443-444.

Schmitt, G., M.E. Stoeckel, and B. Koch. 1981. Evidence for a possible dopaminergic control of pituitary alpha-MSH during ontogenesis in mice. Neuroendocrinology 33: 306-311.

Soinila, S., J. Lakshmanan, and T. Lahtinen. 1988. Nerve-growth factor-like activity in the rat pituitary intermediate lobe. Neurosci. Res. 6: 123-130.

Sousa R., N. Hrinya Tannery, and E.M. Lafer. 1990. Two new monoclonal antibodies provide immunohistochemical evidence for the unique biochemical similarity of the mouse globus pallidus, entopeduncular nucleus, and substantia nigra pars reticulata. Neuroscience 34: 403-410.

Sousa R., N. Hrinya Tannery, S. Zhou, and E.M. Lafer. 1992. Characterization of a novel synapse-specific protein. I. Developmental expression and cellular localization of the F120 protein and mRNA. I. Neurosci. 12: 2130-2143.

Strand, F.L., L.A. Zuccarelli, K.A. Williams, S.J. Lee, T.S. Lee, F.J.Antonawich, A.E. Alves. 1993. Malanotropins as growth factors. Ann. N.Y. Acad. Sci. 680: 29-50.

Szekely, L., W.-Q. Jiang, F. Bulic-Jakus, A. Rosen, N. Ringerz, G. Klein, and K.G. Wilman. 1992. Cell type and differentiation dependent heterogeneity in retinoblastoma protein expression in SCID mouse fetuses. Cell Growth Differ. 3: 149-156.

Tong, Y. and G. Pelletier. 1990. Ontogeny of proopiomelanocortin (POMC) gene expression in the intermediate lobe of the rat pituitary gland. Neuropeptides 16: 173-179.

Voss, J.W. and M.G. Rosenfeld. 1992. Anterior pituitary development: Short tales from dwarf mice. Cell 70: 527-530.

Walkinshaw, G. and C.M. Waters. 1995. Induction of apoptosis in catecholaminergic PC12 cells by L-DOPA. Implications for the treatment of Parkinson's disease. I. Clin. Invest. 95: 2458-2464.

Wiedenmann, B. and W.W. Franke. 1985. Identification and localization of synaptophysin, an integral membrane glycoprotein of $\mathrm{Mr} 38,000$ characteristic of presynaptic vesicles. Cell 41: 1017-1028.
Williams, B.O., L. Remington, D.M. Albert, S. Mukai, R.T. Bronson, and T. Jacks. 1994a. Cooperative tumorigenic effects of germline mutations in $R b$ and p53. Nature Genet. 7: $480-484$

Williams, B.O., E.M. Schmitt, L. Remington, R.T. Bronson, D.M. Albert, R.A. Weinberg, and T. Jacks. 1994b. Extensive contribution of $R b$-deficient cells to adult chimeric mice with limited histopathological consequences. EMBO $J$. 13: 4251-4259.

Ye, W. and E.M. Lafer. 1995. Clathrin binding and assembly activities of expressed domains of the synapse-specific clathrin assembly protein AP-3. J. Biol. Chem. 270: 10933-10939.

Yin, D., S. Kondo, J. Takeuchi, and T. Morimura. 1993. Induction of apoptosis in rat somatotrophin-secreting pituitary adenoma cells by bromocriptine. Oncol. Res. 5: 383-387.

Yin, D., S. Kondo, J. Takeuchi, and T. Morimura. 1994. Induction of apoptosis in murine ACTH-secreting pituitary adenoma cells by bromocriptine. FEBS Lett. 339: 73-75.

Ziv, I., E. Melamed, N. Nardi, D. Luria, A. Achiron, D. Offen, and A. Barzilai. 1994. Dopamine induces apoptosis-like cell death in cultured chick sympathetic neurons-a possible novel pathogenetic mechanism in Parkinson's disease. Neurosci: Lett. 170: 136-140. 


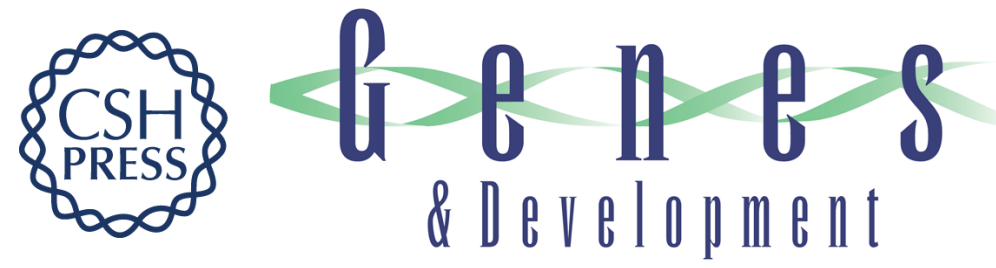

\section{Early loss of the retinoblastoma gene is associated with impaired growth inhibitory innervation during melanotroph carcinogenesis in $\mathbf{R b}+/-$ mice.}

Nikitin AYu and W H Lee

Genes Dev. 1996, 10:

Access the most recent version at doi:10.1101/gad.10.15.1870

References This article cites 49 articles, 13 of which can be accessed free at:

http://genesdev.cshlp.org/content/10/15/1870.full.html\#ref-list-1

License

Email Alerting Service

Receive free email alerts when new articles cite this article - sign up in the box at the top right corner of the article or click here.

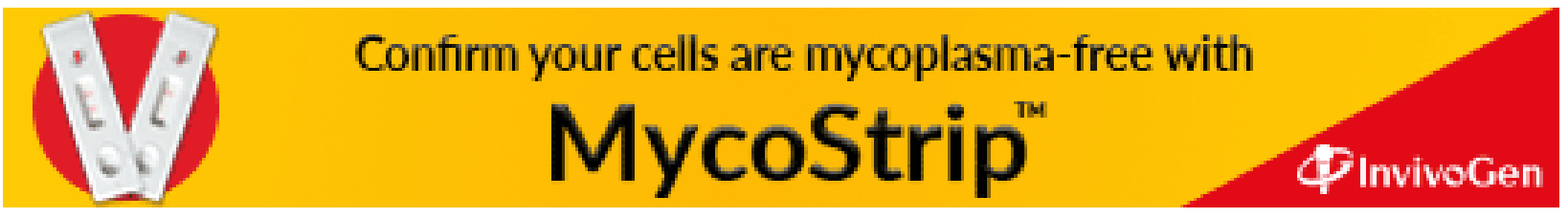

